\title{
Engineering Ethical Curricula: Assessment of Two Approaches and Recommendations
}

\author{
Matthew J. Drake*, Paul M. Griffin*, Robert Kirkman ${ }^{+}$, Julie L. Swann* \\ * School of Industrial \& Systems Engineering \\ ${ }^{+}$School of Public Policy \\ Georgia Institute of Technology \\ Atlanta, GA 30332-0205
}

\begin{abstract}
In this paper, we assess two approaches for delivery of engineering ethics: a full semester ethics course and an engineering course that includes a discipline-specific ethics module. We use the second edition of the Defining Issues Test (DIT) to measure moral reasoning ability. We compare improvement of moral reasoning ability for each class pre and post ethical instruction and compare the results to a control class with no ethical instruction. Although the full term ethics course had more improvement than the single module, neither ethical intervention showed significant improvement over the control group. We also found that there was little distinction between males and females and no distinction by age, although education level did have an impact on ethical judgment. Our results of the experimental groups compared to the control group suggest that the approaches that many universities use to provide ethical instruction to engineers is not sufficient to have an impact on general ethical reasoning ability. We provide recommendations for improving ethics in engineering education, such as an integrative approach delivered at multiple points in the curriculum and incorporating discipline-specific context.
\end{abstract}

\section{Introduction}

The Accreditation Board for Engineering and Technology requires that engineering programs introduce students to ethical issues that arise from the practice of engineering [1]. As a result, many engineering departments have recently worked to incorporate ethics into their already crowded curriculum. In this paper, we compare two general approaches to teaching professional ethics to undergraduate students, with a particular focus on the effectiveness of each mode in improving moral judgment.

The College of Engineering at the Georgia Institute of Technology (Georgia Tech) uses both approaches to teaching engineering ethics. About half of the schools, including Mechanical Engineering and Electrical and Computer Engineering, require students to take a three-credit, semester-length course related to ethics; students choose this course from a menu of options offered by the School of Public Policy and the School of International Affairs, among others. The remaining schools in the College of Engineering have opted for the introduction of ethics-related modules directly into required engineering courses, which is the approach taken by the School of Industrial and Systems Engineering (ISyE). 
The comparison that we perform is between students that took a full course on ethics entitled "Ethics and the Technical Professions" (ETP) offered by the School of Public Policy, and those that took an ISyE course entitled "Modeling in Industrial Engineering" (MIE) which only contained an ethics module as part of its content.

We follow the approach of Self and Ellison [2] in adopting the Defining Issues Test as our instrument. As with all such instruments, the DIT comes with built-in theoretical commitments that need to be well understood in order to properly interpret the data it yields. For a detailed discussion of the DIT and Kohlberg's cognitive theory, please see [3].

\section{Methods}

We compared two classes at Georgia Tech that used various levels of ethical instruction. The first class, "Ethics and the Technical Professions" (ETP) $(\mathrm{N}=129$ of final sample), was a full semester course on ethical reasoning in the context of professional topics offered by the School of Public Policy and taught by a faculty member with a Ph.D. in Philosophy. The class met in a large lecture section on Mondays and Wednesdays, with smaller, TA-led discussion sections on Fridays. Much of the class was focused on helping students develop their skills in analyzing cases, generating a range of possible solutions, and building an argument for their preferred solutions. Weekly writing assignments, three argumentative essays, and an essay-format final exam were likewise based on case studies.

The second class, "Modeling in Industrial Engineering" (MIE) (N=109), was a general introduction to the types of models (conceptual and computational) and methodologies used in the industrial engineering field. These students received two lectures on ethics based and worked through two short ethics cases in class and had an ethics case given as a group lab assignment.

An industrial engineering class, "Probability with Applications" (PA) $(\mathrm{N}=26)$ served as the control group. There was no ethical instruction at all in this class, and in addition, none of the students in this class were enrolled in either of the first two classes, or in another ethics class.

For each student, we tested their ethical reasoning at the beginning of the school term (prior to ethical instruction) and at the end of the term (after ethical instruction), and we matched the pre and post-tests. Tests were deleted if the individual was not at least 18 years old, if they answered randomly, or if they did not fill out important demographic data (e.g., gender or year in school). The overall number of students is shown in Table 1, and the demographics of each class in Table 2 . We should mention that students self-enrolled in the classes and hence it was not possible to randomly assign them (i.e., the design is quasi-experimental). 


\begin{tabular}{|c|c|c|c|c|}
\hline \multirow{3}{*}{$\begin{array}{l}\text { Course: } \\
\text { Students enrolled } \\
\text { (N) } \\
\text { Pre-test only (N) }\end{array}$} & ETP & MIE & $\begin{array}{c}\text { PA } \\
\text { (Control) }\end{array}$ & \multirow{3}{*}{$\begin{array}{c}\text { Total } \\
\\
398 \\
80\end{array}$} \\
\hline & 164 & 148 & 86 & \\
\hline & 21 & 31 & 28 & \\
\hline \multirow{4}{*}{$\begin{array}{l}\text { Pre response rate } \\
\text { All }(\mathrm{N})\end{array}$} & 91.5 & 94.6 & & \multirow{5}{*}{\begin{tabular}{|c}
$86.4 \%$ \\
264 \\
$66.3 \%$
\end{tabular}} \\
\hline & $\%$ & $\%$ & $62.8 \%$ & \\
\hline & 129 & 109 & 26 & \\
\hline & 78.7 & 73.6 & & \\
\hline Final response rate & $\%$ & $\%$ & $30.2 \%$ & \\
\hline
\end{tabular}

\begin{tabular}{|c|c|c|c|c|}
\hline Course: & ETP & MIE & $\begin{array}{c}\text { PA } \\
\text { (Control) }\end{array}$ & Total \\
\hline \multicolumn{5}{|l|}{ Majors } \\
\hline \multicolumn{5}{|l|}{ Industrial } \\
\hline \multirow{2}{*}{$\begin{array}{l}\text { Other Engineering } \\
\text { Non-Engineering }\end{array}$} & $\begin{array}{c}4 \\
114\end{array}$ & 0 & 2 & 116 \\
\hline & 11 & 1 & 1 & 13 \\
\hline \multicolumn{5}{|l|}{ Educational Level } \\
\hline Freshman & 3 & 1 & 4 & 8 \\
\hline \multirow{2}{*}{$\begin{array}{l}\text { Sophomore } \\
\text { Junior }\end{array}$} & 10 & 59 & 13 & 82 \\
\hline & 55 & 39 & 5 & 99 \\
\hline \multirow{2}{*}{$\begin{array}{l}\text { Senior } \\
\text { Other }\end{array}$} & 60 & 7 & 3 & 70 \\
\hline & 1 & 3 & 1 & 5 \\
\hline \multicolumn{5}{|l|}{ Sex } \\
\hline \multicolumn{5}{|l|}{$\begin{array}{l}\text { Sex } \\
\text { Male }\end{array}$} \\
\hline \multirow{2}{*}{$\begin{array}{l}\text { Female } \\
\text { No response }\end{array}$} & 16 & 41 & 9 & 66 \\
\hline & 0 & 1 & 0 & 1 \\
\hline All & 129 & 109 & 26 & 264 \\
\hline
\end{tabular}

The DIT-2 test provides two scores that we used in the analysis: the P score and the N2 index ${ }^{1}$. The $P$ score is a numerical index of moral reasoning that indicates the prevalence of post-conventional thinking on the part of each subject given as a percentage from 0 to 95 . The N2 index is normalized to the same scale as the P score for comparisons. The N2 score

\footnotetext{
${ }^{1}$ The DIT-2 also measures "Type" which indicates the moral reasoning schema preferred by a test-taker and whether the person is primarily in that scheme ("consolidated") or moving to/from another schema ("transitional"). For simplicity we do not include Type in this analysis. The interested reader is referred to Drake et al. [3].
} 
employs both rating and ranking data from the test and typically purges more data points than the $\mathrm{P}$ index due to missing data rules.

We used the "effect size" to indicate the effect of ethical instruction between each of the experimental classes compared to the control group. The effect size is the difference between the experimental and control groups on the change from pre test to post test, divided by the pooled standard deviation. Specifically: Effect size of class $j$ compared to control group $k=$ $\left(\mu_{\mathrm{j}}^{\text {diff }}-\mu_{\mathrm{k}}{ }^{\text {diff }}\right) / \sigma_{\mathrm{jk}}{ }^{\text {diff }}$, where $\mu_{\mathrm{j}}{ }^{\text {diff }}$ is the mean over the individuals in class $j$ of the post test measurement - the pre test measurement for each individual and $\sigma_{\mathrm{jk}}{ }^{\mathrm{diff}}$ is the pooled standard deviation. This is a common way of reporting ethical reasoning scores in experiments with control groups, and it allows us to compare to other studies.

A $t$-test with equal variance was used to test for differences between groups on the P score, N2 score. A Pearson correlation coefficient was used to test for significance of correlations. Significance levels are at the 5\% level unless otherwise indicated.

\section{Results}

Tables 3 and 4 show the mean pre- and post-test scores for students stratified by class as well as the difference between the scores on each test. The effect sizes for the P and N2 scores in the ETP class indicate that the full-term ethics course had a small effect on these measures (since the effect sizes are less than 0.2), while the MIE class did not have an improvement. However, $t$-tests comparing the pre- and post-test differences for each of the experimental classes to the control group difference found that neither form of ethical instruction produced an improvement in any of the measures over that seen in the control group. This suggests that any improvement seen from the pre-test to the post-test is primarily due to the students' familiarity and experience with the test and not the result of ethical instruction. Consequently, the effect sizes described above are not statistically significant; therefore, they must be assumed to be the product of random sampling variation.

\begin{tabular}{|c|c|c|c|c|c|c|c|}
\hline & $\mathbf{N}$ & $\begin{array}{l}\text { Pre } P \\
\text { Score }\end{array}$ & $\begin{array}{l}\text { Post } P \\
\text { Score }\end{array}$ & $\begin{array}{l}\text { Post - } \\
\text { Pre P }\end{array}$ & $\begin{array}{c}\text { Pre N2 } \\
\text { Score }\end{array}$ & $\begin{array}{l}\text { Post N2 } \\
\text { Score }\end{array}$ & $\begin{array}{l}\text { Post - } \\
\text { Pre N2 }\end{array}$ \\
\hline \multicolumn{8}{|l|}{ Course } \\
\hline ETP & 129 & $\begin{array}{r}38.37 \\
(1.29) \\
\end{array}$ & $\begin{array}{r}42.12 \\
(1.36) \\
\end{array}$ & $\begin{array}{c}3.75 \\
(1.20) \\
\end{array}$ & $\begin{array}{r}38.50 \\
(1.29) \\
\end{array}$ & $\begin{array}{r}43.49 \\
(1.31) \\
\end{array}$ & $\begin{array}{r}5.00 \\
(1.03) \\
\end{array}$ \\
\hline $\begin{array}{l}\text { PA } \\
\text { (Control) }\end{array}$ & 26 & $\begin{array}{l}33.85 \\
(2.50) \\
\end{array}$ & $\begin{array}{r}36.08 \\
(2.82) \\
\end{array}$ & $\begin{array}{r}2.23 \\
(2.45) \\
\end{array}$ & $\begin{array}{r}36.41 \\
(2.87) \\
\end{array}$ & $\begin{array}{r}39.39 \\
(2.89) \\
\end{array}$ & $\begin{array}{c}2.98 \\
(2.13) \\
\end{array}$ \\
\hline Effect & & & & 0.11 & & & 0.18 \\
\hline
\end{tabular}

Table 3: Average (standard error) of Pre Test and Post Scores for ETP and the Control group 


\begin{tabular}{|c|c|c|c|c|c|c|c|}
\hline & $\mathbf{N}$ & $\begin{array}{l}\text { Pre P } \\
\text { Score }\end{array}$ & $\begin{array}{l}\text { Post P } \\
\text { Score }\end{array}$ & $\begin{array}{l}\text { Post - } \\
\text { Pre P }\end{array}$ & $\begin{array}{c}\text { Pre N2 } \\
\text { Score }\end{array}$ & $\begin{array}{c}\text { Post N2 } \\
\text { Score }\end{array}$ & $\begin{array}{l}\text { Post - } \\
\text { Pre N2 }\end{array}$ \\
\hline \multicolumn{8}{|l|}{ Course } \\
\hline MIE & 109 & $\begin{array}{c}34.16 \\
(1.35)\end{array}$ & $\begin{array}{r}33.35 \\
(1.40)\end{array}$ & $\begin{array}{c}-0.81 \\
(1.26)\end{array}$ & $\begin{array}{r}36.27 \\
(1.34)\end{array}$ & $\begin{array}{r}35.97 \\
(1.49) \\
\end{array}$ & $\begin{array}{l}-0.30 \\
(1.20)\end{array}$ \\
\hline $\begin{array}{l}\text { PA } \\
\text { (Control) }\end{array}$ & 26 & $\begin{array}{r}33.85 \\
(2.50) \\
\end{array}$ & $\begin{array}{r}36.08 \\
(2.82) \\
\end{array}$ & $\begin{array}{r}2.23 \\
(2.45) \\
\end{array}$ & $\begin{array}{r}36.41 \\
(2.87) \\
\end{array}$ & $\begin{array}{r}39.39 \\
(2.89) \\
\end{array}$ & $\begin{array}{r}2.98 \\
(2.13) \\
\end{array}$ \\
\hline Effect & & & & -0.23 & & & -0.27 \\
\hline
\end{tabular}

Table 4: Average (standard error) of Pre Test and Post Scores for MIE and the Control group

In order to see the effect of demographics, comparisons were made between genders and grade levels (Table 5). The sample sizes for each of the categories differ from each other and from the overall sample size of 264 because some students failed to provide this classification data and some students were not undergraduates. We found no difference between gender, and this coincides with previous research that concludes that gender is not a significant factor in DIT performance $[4,5]$.

With regard to grade level, the results show that the groups did not perform statistically differently on the pre-test but did exhibit a difference on the post-test and in their improvement from the pre-test to the post-test. This suggests that the juniors and seniors were either more receptive to the ethical instruction or benefited more from taking the test a second time. It is also important to note that the educational level designation is key here, because an age variable was not significantly correlated with any of the scores. This provides evidence that educational level has more of an effect on moral reasoning than age does. These results exhibit a bias, however, because most of the upperclassmen were enrolled in the ETP (fulllength) course while underclassmen mainly comprised the MIE course and the control group. Too few students were enrolled in each course's minority educational level to examine the effects of this bias formally.

\begin{tabular}{|l|c|c|c|c|c|c|c|}
\hline \multicolumn{2}{|c|}{ N $\begin{array}{r}\text { Pre P } \\
\text { Score }\end{array}$} & $\begin{array}{c}\text { Post P } \\
\text { Score }\end{array}$ & $\begin{array}{c}\text { Post - } \\
\text { Pre P }\end{array}$ & $\begin{array}{c}\text { Pre N2 } \\
\text { Score }\end{array}$ & $\begin{array}{c}\text { Post N2 } \\
\text { Score }\end{array}$ & $\begin{array}{c}\text { Post - } \\
\text { Pre N2 }\end{array}$ \\
\hline Male & 197 & 36.58 & 39.00 & 2.41 & 37.74 & 40.85 & 3.12 \\
\hline Female & 66 & 34.95 & 34.68 & -0.27 & 36.36 & 37.40 & 1.05 \\
\hline $\begin{array}{l}\text { P-value of difference } \\
\text { between genders }\end{array}$ & & 0.42 & 0.05 & 0.16 & 0.50 & 0.12 & 0.23 \\
\hline
\end{tabular}

\section{Grade Level}

\begin{tabular}{|l|c|c|c|c|c|c|c|}
\hline $\begin{array}{l}\text { Freshmen and } \\
\text { sophomores }\end{array}$ & 90 & 35.83 & 35.02 & -0.81 & 37.41 & 37.32 & -0.09 \\
\hline Juniors and seniors & 169 & 36.84 & 39.79 & 2.95 & 37.76 & 41.85 & 4.09 \\
\hline $\begin{array}{l}\text { P-value of difference } \\
\text { between grade levels }\end{array}$ & & 0.59 & $\mathbf{0 . 0 2}$ & $\mathbf{0 . 0 3}$ & 0.85 & $\mathbf{0 . 0 2}$ & $\mathbf{0 . 0 1}$ \\
\hline
\end{tabular}

Table 5: Average of Pre-Test and Post Scores for Student Demographic Groups 


\section{Conclusions}

Previous studies have stated that a minimum of three weeks of ethics coverage is required to make an impact [6], and our study concurs. However, we find that even a full course on ethics did not make a significant increase in moral reasoning (when compared to a control group). This differs from the results of Self and Ellison [1], we do show a significant impact of the full ethics course on moral reasoning. One possible reason for this difference was due to the fact that we included a control group in our study (since if we ignored the control, we would draw the same conclusion). It is also possible that content played a role. For example, engineering ethics taught in the context of the student's discipline could have a larger impact than a general engineering ethics course. Since Self and Ellison did not describe the content of their course, this is speculation on our part.

Based on experiences from performing this study, we feel that there are multiple important components in developing effective engineering ethics curriculum. First, the material should include discipline-specific content. For example, in Industrial Engineering, coverage of production planning could include the ethical issues around layoffs and outsourcing. Although this may or may not affect a student's moral reasoning, it does increase their sensitivity or awareness to ethical dilemmas, including some norms of professional practice. Second, the material should integrate various aspects of engineering curricula. In this way, ethics is not viewed as something distinct from engineering, but as part of the problemsolving process. Integrating ethics in the learning experience does not necessarily mean in a classroom setting. One possibility is to use service learning (engineering projects in non-profit organizations or needy areas) to promote understanding of ethical dilemmas and the potential impact of technology. Finally, in order to reinforce the material, it should be provided at multiple points in the curriculum.

There are several limitations to the study that must be considered. First, the DIT-2 is an imperfect measure of ethics. As noted earlier, the DIT-2 measures only one component of moral conduct and not the students' ability to recognize situations that call for ethical judgment. Second, there were limitations of sampling in that a limited range of sizes and types of ethics classes or modular options were considered. Finally, there is a limitation of time, in that our study spanned only one semester.

Our study serves as an initial comparison with modest implications for curriculum design and implementation, implications that must be developed and tested further in subsequent studies at Georgia Tech and elsewhere. The study also provides evidence of the need to improve our

methods for incorporating ethics education in engineering, and the research has also helped to identify some of the avenues for this improvement.

\section{References}

[1] ABET_Engineering_Accreditation_Commission. Criteria for Accrediting Engineering Programs 2002 [cited Sept 21, 2004. Available from http://www.abet.org/criteria eac.html. 
[2] Self, D.J., and E.M. Ellison, "Teaching Engineering Ethics: Assessment of Its Influence on Moral Reasoning Skills," Journal of Engineering Education, vol. 87, no. 1, 1998, pp. 2934.

[3] Drake, M., Griffin, P., Kirkman, R., and Swann, J., "Engineering Ethical Curricula: Assessment and Comparison of Two Approaches," Journal of Engineering Education, to appear.

[4] Rest, J., Development in judging moral issues, University of Minnesota Press, Minneapolis, 1979.

[5] Thoma, S.J., "Do moral education programs facilitate moral judgment? A meta-anaylsis of studies using the Defining Issues Test," Moral Education Forum, vol. 9, no. 4, 1984, pp. 20-25.

[6] Schaefli, A., J. Rest, and S. Thoma, "Does moral education improve moral judgment? A meta-analysis of intervention studies using the Defining Issues Test," Review of Educational Research, vol. 55, no. 3, 1985, pp. 319-352. 